\title{
An NMDA Receptor ER Retention Signal Regulated by Phosphorylation and Alternative Splicing
}

\author{
Derek B. Scott, ${ }^{1,2}$ Thomas A. Blanpied, ${ }^{2}$ Geoffrey T. Swanson,, ${ }^{3}$ Chi Zhang, ${ }^{2}$ and Michael D. Ehlers ${ }^{1,2}$ \\ ${ }^{1}$ Program in Cell and Molecular Biology and ${ }^{2}$ Department of Neurobiology, Duke University Medical Center, Durham, \\ North Carolina 27710, and ${ }^{3}$ Molecular Neurobiology Laboratory, The Salk Institute, La Jolla, California 92037
}

Formation of mature excitatory synapses requires the assembly and delivery of NMDA receptors to the neuronal plasma membrane. A key step in the trafficking of NMDA receptors to synapses is the exit of newly assembled receptors from the endoplasmic reticulum (ER). Here we report the identification of an RXR-type ER retention/retrieval motif in the C-terminal tail of the NMDA receptor subunit NR1 that regulates receptor surface expression in heterologous cells and in neurons. In addition, we show that PKC phosphorylation and an alternatively spliced

NMDA receptors are glutamate-gated ion channels that play a central role in synapse formation, synaptic plasticity, and neurological disease (Mori and Mishina, 1995; Ozawa et al., 1998; Malenka and Nicoll, 1999). These receptors are composed of heteromeric combinations of NR1 and NR2 subunits that cotranslationally assemble in the endoplasmic reticulum (ER) to form functional channels (Monyer et al., 1992; McIlhinney et al., 1998; Ozawa et al., 1998). After being assembled, NMDA receptors are selectively targeted to the postsynaptic membrane opposite glutamatergic terminals (O'Brien et al., 1998) and appear at nascent synapses within 1-2 hr of initial contact by an active presynaptic terminal (Friedman et al., 2000). At more mature synapses, new NMDA receptors are delivered to the postsynaptic membrane in response to experience-dependent synaptic activation (Quinlan et al., 1999), and synaptic accumulation of NMDA receptors is reciprocally regulated by chronic changes in activity (Rao and Craig, 1997; Liao et al., 1999; Watt et al., 2000). The synaptic localization of NMDA receptors arises, in part, via protein-protein interactions that anchor or stabilize NMDA receptors in the postsynaptic density (O'Brien et al., 1998; Sheng and Lee, 2000). However, before becoming localized at synapses, newly synthesized NMDA receptors must assemble, mature, and be transported through the ER-Golgi secretory pathway (McIlhinney et al., 1998), a set of processes that remains poorly understood.

\footnotetext{
Received Dec. 8, 2000; revised Feb. 2, 2001; accepted Feb. 5, 2001.

This work was supported by a Ruth K. Broad fellowship (D.B.S.) and grants from the National Institutes of Health (RO1 NS39402), the Spinal Cord Research Foundation, the McKnight Foundation, the Klingenstein Fund, the Triangle Community Foundation, the Alfred P. Sloan Foundation, the American Health Assistance Foundation, the North Carolina Biotechnology Center, and the National Alliance for Research on Schizophrenia and Depression (M.D.E.). We thank Dr. Pierre Cosson for providing the Tac construct. In addition, we thank Y. Mu for making constructs, C. Nicchitta for supplying the Trap $\alpha$ antibody, and K. Courtney for supplying the mannosidase II antibody. Special thanks to S. Heinemann for support of the electrophysiology experiments.

Correspondence should be addressed to Dr. Michael D. Ehlers, Department of Neurobiology, Duke University Medical Center, Durham, NC 27710. E-mail: ehlers@neuro.duke.edu.

Copyright (c) 2001 Society for Neuroscience $\quad 0270-6474 / 01 / 210001-10 \$ 15.00 / 0$
}

consensus type I PDZ-binding domain suppress ER retention. These results demonstrate a novel quality control function for alternatively spliced C-terminal domains of NR1 and implicate both phosphorylation and potential PDZ-mediated interactions in the trafficking of NMDA receptors through early stages of the secretory pathway.

Key words: ER retention; NMDA receptors; NR1 subunit; $R X R$ motif; quality control mechanisms; intracellular trafficking

The plasma membrane delivery of multimeric protein complexes requires proper folding and assembly of their constituent subunits. In many cases, the masking of specific ER retention/ retrieval motifs during receptor assembly regulates the forward trafficking of ion channels and other membrane proteins through the secretory pathway (Zerangue et al., 1999; Bichet et al., 2000; Margeta-Mitrovic et al., 2000). For example, RXR-type ER retention motifs found in each of the ATP-sensitive potassium channel $\left(\mathrm{K}_{\mathrm{ATP}}\right)$ subunits Kir6.1, Kir6.2, and SUR1 are sequentially masked during subunit oligomerization, thus assuring that only correctly assembled channels reach the plasma membrane (Zerangue et al., 1999). A similar RXR motif present in $\mathrm{GABA}_{\mathrm{B}}$ receptor GB1 subunits is masked by assembly with GB2, ensuring heterodimerization (Margeta-Mitrovic et al., 2000). Also, surface expression of $\mathrm{Ca}^{2+}$ channels is facilitated by $\beta$ subunits, which mask ER retention domains in $\alpha$ subunits (Bichet et al., 2000). Like these membrane proteins, NMDA receptors possess intracellular regulatory domains that influence intracellular trafficking of mature channels. In particular, mRNA splicing of the NR1 C terminal affects the surface expression (Okabe et al., 1999) and intracellular localization (Ehlers et al., 1995) of NMDA receptors.

Recent studies suggest that specific quality control mechanisms exist for recognizing and retaining unassembled NMDA receptor subunits and releasing only properly assembled receptors from the ER. When expressed alone in heterologous cells, NR1 and NR2 subunits are retained in the ER and do not efficiently reach the plasma membrane (Ehlers et al., 1995; McIlhinney et al., 1996; Okabe et al., 1999). In neurons, NR1 subunits exist in two populations: a very stable plasma membrane pool and a shortlived intracellular pool that likely represents receptors that have failed to assemble with NR2 subunits (Hall and Soderling, 1997; Huh and Wenthold, 1999). Such rapid degradation of unassembled NR1 subunits ensures that only functional, properly assembled NR1/NR2 heteromeric channels reach the plasma membrane. Despite these initial findings, little is known about the molecular determinants of NMDA receptor assembly and quality 
control or the mechanisms that regulate the delivery of mature channels to the neuronal plasma membrane.

In this study, we report the identification of a novel RXR-type ER retention/retrieval motif present in the alternatively spliced C1 domain of the NMDA receptor subunit NR1. This RXR sequence functions as an ER retention motif in heterologous cells and in neurons. Furthermore, ER retention mediated by the RXR motif is suppressed by the presence of an adjacent alternatively spliced domain containing a consensus type I PDZ-binding sequence and by PKC phosphorylation of specific serine residues in the $\mathrm{C} 1$ domain of NR1. Together, these results identify ER retention, PKC phosphorylation, and alternative splicing of NR1 as novel mechanisms regulating the intracellular trafficking and plasma membrane delivery of NMDA receptors.

\section{MATERIALS AND METHODS}

Cell culture. COS cells were grown in DMEM (Sigma, St. Louis, MO) supplemented with $10 \%$ bovine serum, $1 \mathrm{~mm}$ sodium pyruvate, and 50 $\mathrm{U} / \mathrm{ml}$ penicillin and streptomycin. Human embryonic kidney 293 (HEK293) cells were grown in MEM (Sigma) supplemented with 10\% bovine serum, $1 \mathrm{~mm}$ sodium pyruvate, and $50 \mathrm{U} / \mathrm{ml}$ penicillin and streptomycin. Rat1 cells were grown in DMEM supplemented with 5\% bovine serum, $1 \mathrm{~mm}$ sodium pyruvate, $100 \mu \mathrm{M}$ nonessential amino acids, and $50 \mathrm{U} / \mathrm{ml}$ penicillin and streptomycin. Primary cultures of hippocampal neurons were obtained from 1-d-old rat pups. Area CA1 was isolated and dissociated with trypsin, and cells were plated at $60,000 \mathrm{cells} / \mathrm{cm}^{2}$ in Neurobasal medium (Sigma) supplemented with B27, glutamax I, 5\% bovine serum, and $1 \mu \mathrm{g} / \mathrm{ml}$ gentamycin. FUDR $(10 \mu \mathrm{M})$ was added $1-3$ $\mathrm{d}$ after plating, and cells were fed twice weekly thereafter. Hippocampal neurons and COS cells were grown on coverslips coated with poly-Dlysine (Sigma). All cells were grown at $37^{\circ} \mathrm{C}$ and in $5 \% \mathrm{CO}_{2}$.

Generation of Tac-NR1 receptors. Tac receptors fused with intracellular NR1 C-terminal domains were generated by first amplifying NR1 $\mathrm{C}$-terminal domains with the following sets of primers: C0 (forward, 5'-CCCAAGCTTCCGAGATCGCCTACAAGCGAC-3'; reverse, 5'-CCCAAGCTTGGATCCTCACTGCAGGTTCTTCCTCCAC-3'), C1(forward, 5'-CCCAAGCTTATAGAAAGAGTGGTAGAGC-3'; reverse, 5'-CCCAAGCTTGGATCCTCACGTGTCTTTGGAGGA CCTAC-3'),C2(forward, 5'-CCCAAGCTTCCAGCACCGGGGGTGGACGC-3'; reverse, 5'GCTCTAGATCAGCTCTCCCTATGAC-3'), C2' (forward, 5'-CCCAAGCTTCCCAGTACCATCCCACTGAT-3'; reverse, 5'-GCTCTAGATCACACCACGGTGCTGACCGAGGG-3'), NR1a/NR1c/allmutant NR1a (forward, 5'-CCCAAGCTTCCGAGAT CCCTACAAGCGAC-3'; reverse, 5'-CCCAAGCTTGGATCCTCAG CTCTCCCTATGAC-3'), NR1e (forward, 5'-CCCAAGCTTCCGAGATCCGGTACAAGCGAC-3'; reverse, $5^{\prime}$-CCCAAGCTTGGAT CCTCACACCACGGTGCTGACCGAGGG-3'), NR1g (forward, 5' CCCAAGCTTCCGAGATCCGGTACAAGCGAC-3'; reverse, 5' GCTCTAGATCACACCACGGTGCTGACCGAGGG-3'), and NR1e $\triangle$ VSTVV (forward, 5'-CCCAAGCTTCCGAGATCCGGTACAAGCGAC-3'; reverse, 5'-CCCAAGCTTGGATCCTCACGAGGGATCTGAGAGGTTGAGCGG-3'). After digestion with HindIII plus $X b a \mathrm{I}(\mathrm{C} 2$, C2', and NR1g) or HindIII (C0, C1, NR1a/NR1c/NR1e, NR1a point mutants, and NR1e $\triangle$ VSTVV), PCR fragments were ligated into linearized Tac pCDM8 expression vector (kindly provided by Dr. P. Cosson, Center Medical Universitaire, Geneva, Switzerland). Tac-NR1a point mutants were first generated in full-length NR1a subunits using the quick change site-directed mutagenesis kit (Stratagene, La Jolla, CA), following the manufacturer's instructions, and then fused with Tac as described above. GluR1(o)-C1 was generated as described (Ehlers et al., 1995). All constructs were verified by sequencing.

Transfections. COS, HEK293, and Rat1 cells were transfected using the Superfect Transfection Reagent (Qiagen, Valencia, CA) following the manufacturer's suggested protocol for transient transfection of adherent cells. Seven- to 14-d-old cultured hippocampal neurons were transfected using the LipofectAMINE 2000 Transfection Reagent (Life Technologies, Gaithersburg, MD). Briefly, 1-2 $\mu \mathrm{g}$ of DNA in $50 \mu \mathrm{l}$ of OptiMEM (Life Technologies) was mixed with $0.5 \mu \mathrm{l}$ of LipofectAMINE 2000 in $100 \mu \mathrm{l}$ of OptiMEM and incubated at room temperature for $20 \mathrm{~min}$. The transfection cocktail was then added directly to neurons plated onto coverslips in $2 \mathrm{ml}$ of culture media and incubated at $37^{\circ} \mathrm{C}$ and in $5 \% \mathrm{CO}_{2}$. Expression in all cell types was analyzed $24-48 \mathrm{hr}$ after transfection.

Antibodies. Monoclonal anti-Tac antibody (Covance, Princeton, NJ) was used as follows: 1:500 (immunofluorescence of heterologous cells), 1:2500 (neurons), and 1:5000 [fluorescence-activated cell (FAC) sorter]. Polyclonal anti-Tac antibody (Santa Cruz Biotechnology, Santa Cruz, CA) was used as follows: 1:100 (immunofluorescence of heterologous cells) and 1:1000 (Western blots). Polyclonal anti-C1 (1747), anti-C2 (1683), anti-C2' (1233), and anti-Trap $\alpha$ (kindly provided by Dr. C. Nicchitta, Duke University, Durham, NC) and monoclonal anti-BiP (Transduction Laboratories, San Diego, CA) antibodies were all used at 1:100. Monoclonal anti-mannosidase II (Covance) was used at 1:1000. All secondary antibodies conjugated to indocarbocyanine (Cy3), FITC, or phosphatidylethanolamine (PE) (Jackson ImmunoResearch, West Grove, PA) were used at 1:100.

Immunofluorescence. For surface labeling of heterologous cells, transfected cells were incubated live with anti-Tac antibodies in DMEM supplemented with $5 \%$ serum for $1 \mathrm{hr}$ at $4^{\circ} \mathrm{C}$. Cells were washed with PBS, fixed on ice with $4 \%$ paraformaldehyde and $4 \%$ sucrose for $20 \mathrm{~min}$, washed three times with PBS, and permeabilized with $0.2 \%$ Triton X-100 for $5 \mathrm{~min}$ at room temperature. Intracellular expression was then determined by washing cells with PBS and incubating cells with the appropriate antibody in DMEM supplemented with $5 \%$ serum at room temperature for $2 \mathrm{hr}$. After three washes with PBS, cells were incubated with the appropriate secondary antibodies in DMEM supplemented with 5\% serum for $1 \mathrm{hr}$ at room temperature. Surface and intracellular expression was captured on an epifluorescent microscope (Nikon, Melville, NY) using a cooled CCD camera (Princeton Instruments, Monmouth, NJ) and analyzed with Metamorph imaging software (Universal Imaging Company, West Chester, PA). Colocalization images were visualized and captured with a confocal microscope (LSM410; Zeiss, Thornwood, NY). Immunofluorescent localization of receptors in 7- to 14-d-old cultured hippocampal neurons was achieved as described above, but with two notable exceptions. First, live neurons were incubated with a monoclonal anti-Tac antibody in extracellular buffer $(120 \mathrm{~mm} \mathrm{NaCl}, 3 \mathrm{~mm} \mathrm{KCl}, 10$ $\mathrm{mM}$ HEPES, $2 \mathrm{~mm} \mathrm{CaCl}_{2}, 2 \mathrm{~mm} \mathrm{MgCl}_{2}$, and $10 \mathrm{~mm}$ glucose, $\mathrm{pH} 7.35$ ) plus $5 \%$ donkey serum for $15 \mathrm{~min}$ at $37^{\circ} \mathrm{C}$ or $30 \mathrm{~min}$ at room temperature and then fixed and incubated with a Cy3-conjugated anti-mouse secondary antibody. Second, to identify intracellular expression, neurons were permeabilized and incubated with a monoclonal anti-Tac antibody in $10 \%$ donkey serum followed by incubation with a FITC-conjugated anti-mouse secondary antibody. For quantification of surface labeling using flow-assisted cytometry, live transfected HEK293 cells grown in 6or 12-well tissue culture-treated plates (Corning, Corning, NY) were incubated with a monoclonal anti-Tac antibody in DMEM supplemented with $5 \%$ serum for $1 \mathrm{hr}$ at $4^{\circ} \mathrm{C}$. Cells were then washed with PBS and incubated with a PE-conjugated anti-mouse antibody in PBS for $1 \mathrm{hr}$ at $4^{\circ} \mathrm{C}$, after which cells were washed with PBS, gently detached from the bottom of the plate with $500 \mu \mathrm{l}$ of PBS plus $5 \mathrm{~mm}$ EDTA, and added to $200 \mu \mathrm{l}$ of $4 \%$ paraformaldehyde in $12 \times 75 \mathrm{~mm}$ round-bottom test tubes (VWR Scientific, South Plainfield, NJ). Surface expression was quantified 12-24 hr later using the Becton Dickinson FACscan sorter at the Duke University Flow Facility. Light scattering was used to gate live cells, and the background fluorescence was determined using HEK293 cells transfected with Tac but incubated without the primary antibody. The average fluorescence intensity was calculated for cells registering a fluorescence signal above a background level determined by measuring the fluorescent intensity of cells transfected with Tac but incubated only with the secondary antibody (Tac-primary).

Electrophysiology. HEK293 cells were maintained in DMEM plus $10 \%$ fetal calf serum and were calcium phosphate-transfected with $0.5-1 \mu \mathrm{g}$ of rat GluR1(o) or GluR1(o)-C1 cDNA and $0.2 \mu \mathrm{g}$ of human CD8 antigen cDNA per glass coverslip for $5-12 \mathrm{hr}$ at $37^{\circ} \mathrm{C}$ and in $5 \% \mathrm{CO}_{2}$. Electrophysiological recordings were made $2 \mathrm{~d}$ after transfection. To visualize transfected cells, coverslips were incubated with polystyrene beads coated with anti-CD8 antibody (Dynal, Lake Success, NY) before transferring them to the recording bath chamber. Rapid agonist application was performed by lifting cells into a laminar solution stream that was displaced by a piezobimorph under the control of pClamp 8 software (Axon Instruments, Foster City, CA). Data were acquired and analyzed using pClamp 8 software and Origin 6.0 (OriginLab Corporation, Northampton, MA). The internal pipette solution was composed of 110 mM CsF, $30 \mathrm{~mm} \mathrm{CsCl}, 4 \mathrm{~mm} \mathrm{NaCl}, 0.5 \mathrm{~mm} \mathrm{CaCl}_{2}, 10 \mathrm{~mm}$ HEPES, and 5 mM EGTA, adjusted to $\mathrm{pH} 7.3$ with $\mathrm{CsOH}$. The external bath solution contained $150 \mathrm{mM} \mathrm{NaCl}$, $2.8 \mathrm{~mm} \mathrm{KCl}, 2 \mathrm{mM} \mathrm{CaCl}_{2}, 1.0 \mathrm{mM} \mathrm{MgCl}_{2}$, and 
$10 \mathrm{~mm}$ HEPES; pH was adjusted to 7.3 with $\mathrm{NaOH}$. L-Glutamate was purchased from Sigma.

In vitro deglycosylation. Transfected COS cells washed once with TBS were scraped off the bottom of a $60 \mathrm{~mm}$ plate in $600 \mu \mathrm{l}$ of lysis buffer (PBS, pH 8.0, plus $2 \mathrm{~mm}$ EDTA, $0.1 \mathrm{~mm}$ PMSF, $1 \mu \mathrm{g} / \mathrm{ml}$ pepstatin A, 1 $\mu \mathrm{g} / \mathrm{ml}$ chemostatin, and $1 \mu \mathrm{g} / \mathrm{ml}$ leupeptin). After brief sonication and centrifugation $\left(60,000 \mathrm{rpm}\right.$ for $15 \mathrm{~min}$ at $\left.4^{\circ} \mathrm{C}\right)$, cell membranes were resuspended in $50 \mu \mathrm{l}$ of lysis buffer plus $1 \%$ SDS and boiled for $5 \mathrm{~min}$ before adding $250 \mu \mathrm{l}$ of $1 \%$ octylglucoside and incubating at $4^{\circ} \mathrm{C}$ overnight. Samples were then divided into thirds and treated with either $6 \mathrm{U}$ of peptide- $N$-glycosidase F (PNGase F; Boehringer Mannheim, Indianapolis, IN), $0.1 \mathrm{U}$ of endoglycosidase $\mathrm{H}$ (endo $\mathrm{H}$; Boehringer Mannheim), or no enzyme at all and incubated at $37^{\circ} \mathrm{C}$ for $5 \mathrm{hr}$. After incubations, cell membranes were stored at $-70^{\circ} \mathrm{C}$. After thawing, adding sample buffer, and boiling for $5 \mathrm{~min}$, membrane proteins were resolved on a $7.5 \%$ SDS-PAGE gel and visualized using immunoblot analysis with an anti-Tac polyclonal antibody.

PKC activation experiments. COS7 cells transfected with either TacNR1a or Tac-NR1a SS896-7AA were treated with $100 \mathrm{~nm}$ phorbol 12-myristate 13-acetate (PMA) for $30 \mathrm{~min}$, washed with warm media, and then allowed to recover at $37^{\circ} \mathrm{C}$ for $2-3 \mathrm{hr}$. Cells were then examined for surface and intracellular expression as described above using anti-Tac and anti-C2 antibodies. Quantification of surface expression was accomplished by counting the number of cells showing intracellular expression of Tac-NR1 receptors (anti-C2 positives) and then determining how many of those also showed surface expression of Tac-NR1 receptors (anti-Tac positive). All cell counts were done in a blind manner.

\section{RESULTS}

\section{Identification of trafficking signals in the $\mathrm{C}$ terminal domain of NR1}

The intracellular $\mathrm{C}$ terminal domain of the NMDA receptor subunit NR1 undergoes differential mRNA splicing to create eight different subtypes of NR1 subunits, NR1a-h (Fig. 1A). When expressed alone in heterologous cells, these subtypes exhibit differential subcellular localization (Ehlers et al., 1995) and are differentially expressed at the cell surface (Okabe et al., 1999; Standley et al., 2000) (data not shown). To determine which domains of NR1 are responsible for regulating NR1 surface expression, we constructed chimeric receptor molecules consisting of the human interleukin-2 receptor $\alpha$ subunit (Tac) tagged with portions of the intracellular $\mathrm{C}$ terminal domain of the NR1 subunit (Leonard et al., 1983; Tan et al., 1998; Craven and Bredt, 2000). After expressing these Tac-NR1 constructs in COS7 cells, we visualized receptors that trafficked to the plasma membrane using live immunofluorescence (Fig. 1B). Tac itself showed strong surface expression, as did Tac-C0, Tac-C2, Tac-C2', and $\mathrm{Tac}-\mathrm{C} 0-\mathrm{C} 2$ (Tac-NR1c). In contrast, the $\mathrm{C} 1$-containing receptors $\mathrm{Tac}-\mathrm{C} 1$ and $\mathrm{Tac}-\mathrm{C} 0-\mathrm{C} 1-\mathrm{C} 2$ (Tac-NR1a) were not detectable on the cell surface despite intense intracellular labeling (Fig. 1B).

To quantify surface expression of Tac-NR1 receptors, flowassisted cytometry was performed on transfected HEK293 cells surface labeled with anti-Tac antibody and fluorophoreconjugated secondary antibody. Cells expressing Tac had between a 16- and 31-fold higher surface fluorescence compared with that of Tac-C1 and Tac-NR1a (Fig. 1C). In addition, chimeric receptors without the $\mathrm{C} 1$ domain had an average surface fluorescence 9- to 25-fold higher than that of Tac-C1 or TacNR1a (Fig. 1C). In all cases, total protein expression for various Tac-NR1 receptors was similar as revealed by immunoblot (data not shown) and by staining of permeabilized cells (Fig. 1B, right).

To ensure that regulation of surface expression by the $\mathrm{C} 1$ domain was not specific for Tac receptors expressed in COS7 or HEK293 cells, we first transfected 7- to 14-d-old cultured hippocampal neurons with Tac chimeras and analyzed their surface expression. As in heterologous cells, Tac-C1 and Tac-NR1a were retained intracellularly and did not reach the plasma membrane when expressed in hippocampal neurons. In contrast, Tac, Tac-C0, Tac-C2, Tac-C2', and Tac-NR1c were all efficiently trafficked to the neuronal plasma membrane (Fig. 1D). Second, we asked whether the $\mathrm{C} 1$ domain could regulate the assembly and plasma membrane trafficking of multimeric glutamate receptors. For these experiments, we inserted the $\mathrm{C} 1$ domain into a corresponding site in the intracellular $\mathrm{C}$ terminal domain of the AMPA receptor GluR1(o) subunit, which by itself can form functional homomeric channels (Ozawa et al., 1998), and measured glutamate-induced currents from transfected HEK293 cells (Fig. 2A). Cells expressing GluR1(o) exhibited robust responses to $10 \mathrm{~mm}$ glutamate $(767 \pm 287 \mathrm{pA})$ consistent with homomeric GluR1 channels, whereas cells expressing GluR1(o)-C1 produced almost no response to glutamate $(17 \pm 10 \mathrm{pA})$ (Fig. $2 \mathrm{~B})$. In all cases, total protein levels of GluR1(o) and GluR1(o)-C1 were indistinguishable (data not shown), indicating that addition of the $\mathrm{C} 1$ domain prevented the trafficking of functional GluR1 homomeric AMPA receptors to the plasma membrane. Together, these data demonstrate that the $\mathrm{C} 1$ domain is sufficient to prohibit the surface expression of Tac receptors and glutamate receptors in both heterologous cells and neurons.

\section{The $\mathbf{C 1}$ domain contains an RXR-type ER retention/retrieval motif}

To determine whether the $\mathrm{C} 1$ domain of NR1 prevents surface expression by retaining receptors in the ER, we first examined the subcellular localization of Tac-C1 and Tac-NR1a using confocal microscopy. After transfection of COS7 or Rat1 cells, both Tac-C1 and Tac-NR1a colocalized extensively with the ER resident proteins Trap $\alpha$ (Fig. 3A) and BiP (Fig. 3B) (Sanders and Schekman, 1992; Hartmann and Prehn, 1994) but not with the medial Golgi protein mannosidase II (Burke et al., 1982) (Fig. $3 C$ ). In agreement with a failure of Tac-C1 and Tac-NR1a to reach the medial Golgi, these receptors remained sensitive to endo $\mathrm{H}$ (Fig. $3 D$ ), an enzyme that preferentially hydrolyzes the high mannose $N$-glycans present on immature secretory proteins in the ER (Trimble and Maley, 1984). In contrast, Tac, Tac-C0, Tac-C2, Tac-C2', and Tac-NR1c were resistant to endo H (Fig. $3 D$ ) indicating that these receptors had been processed in the Golgi, a result consistent with their robust surface expression (Fig. $1 B, C$ ). Note that Tac receptors are normally present as both a mature, high-molecular weight, endo H-resistant species and an immature endo $\mathrm{H}$-sensitive species that migrates at a lower molecular weight (Leonard et al., 1983) (Fig. 3D, top panel). The lack of a mature form of either Tac-C1 or Tac-NR1a further suggests that these receptors are unable to exit the ER. However, to ensure that endo $\mathrm{H}$ treatment was selectively deglycosylating Tac-C1 and Tac-NR1a, we incubated chimeric receptors with a lessselective glycosidase, PNGase F, which cleaves almost all types of asparagine-bound $N$-glycans (Tarentino et al., 1985). After incubation with PNGase F, all Tac-NR1 receptors exhibited increased electrophoretic mobility, indicating PNGase F sensitivity (Fig. 3D). These experiments provide strong biochemical and immunocytochemical evidence of selective ER retention of $\mathrm{C} 1$ domain-containing receptors.

Sequence comparisons between the C1 domain of NR1 and the $\mathrm{K}_{\mathrm{ATP}}$ subunits Kir6.1 and Kir6.2 revealed that the $\mathrm{C} 1$ domain shares homology around the newly identified RXR ER retention/ retrieval motif of the $\mathrm{K}_{\mathrm{ATP}}$ channel (Fig. 4A) (Zerangue et al., 1999). To determine which residues are necessary for ER reten- 

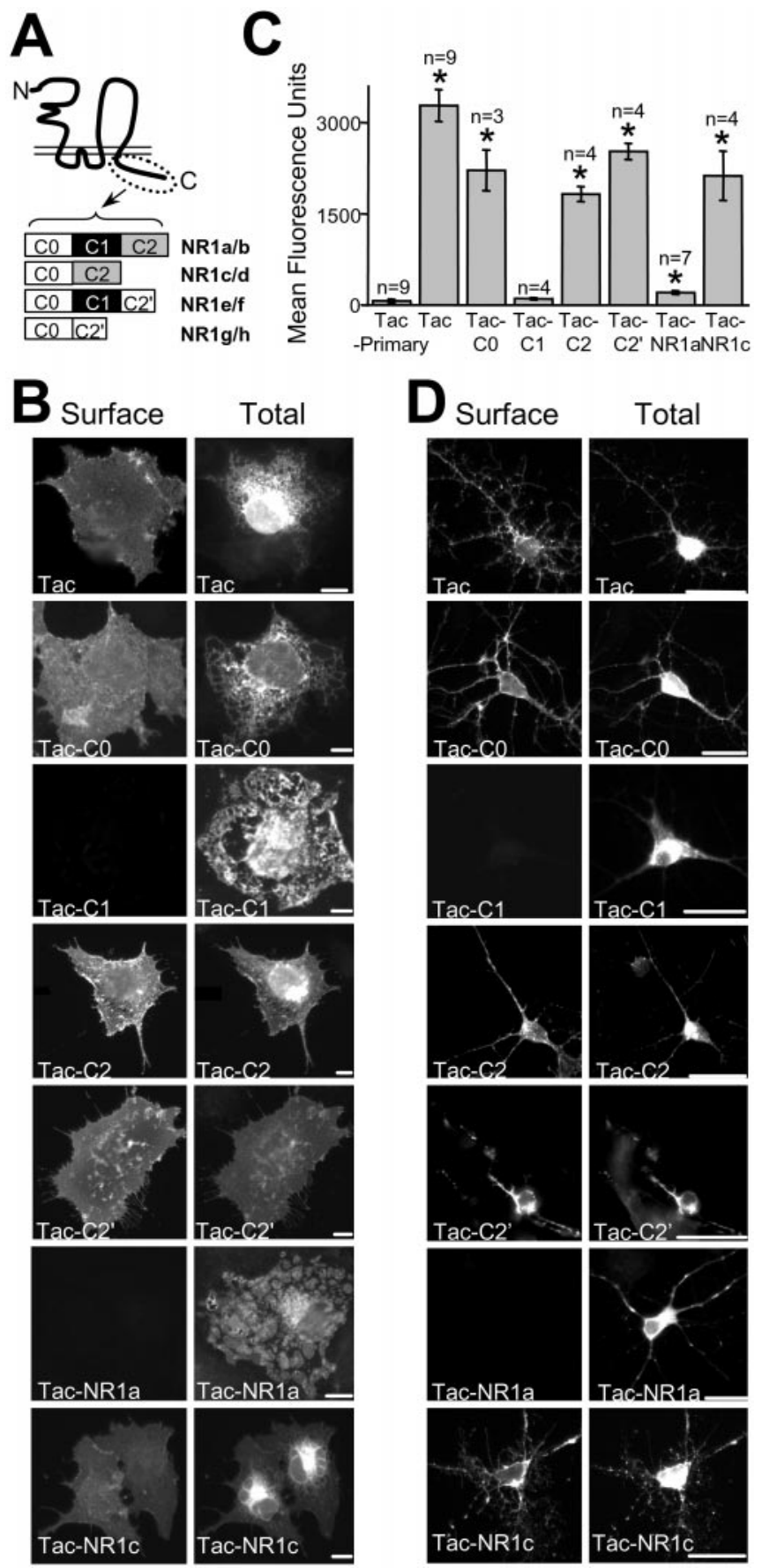

Figure 1. The $\mathrm{C} 1$ domain of NR1 regulates surface expression of chimeric receptors in both heterologous cells and hippocampal neurons. $A$, Schematic representation of NR1 splice variants possessing distinct intracellular domains is shown. The $\mathrm{N}$ terminal $(N)$ and $\mathrm{C}$ terminal $(C)$ ends of the protein are indicated. $B$, Surface and total expression of Tac-NR1 receptors in COS cells is shown. Live cells were labeled with a monoclonal anti-Tac antibody (Surface, left), permeabilized, and labeled with polyclonal anti-Tac (Tac, Tac-C0), anti-C1 (Tac-C1, Tac-NR1a), anti-C2 (Tac-C2, Tac-NR1c), or anti-C2' (Tac-C2') antibodies (Total, right). The C1containing receptors Tac- $\mathrm{C} 1$ and Tac-NR1a are not expressed on the cell surface. $C$, Quantification of Tac-NR1 chimeric receptor surface expression by flow-assisted cytometry is shown. Data represent means \pm SEM of fluorescence intensity of transfected HEK293 cells stained live for the presence of Tac on the cell surface $\left({ }^{*} p<0.05\right.$ relative to Tac minus primary antibody control, one-way ANOVA). $D$, C1-containing receptors do not reach the plasma membrane of cultured hippocampal neurons. Surface (left) and total (right) receptors were localized by immunofluorescence as described in $A$. Scale bars: $B, 10 \mu \mathrm{m} ; D, 25 \mu \mathrm{m}$.
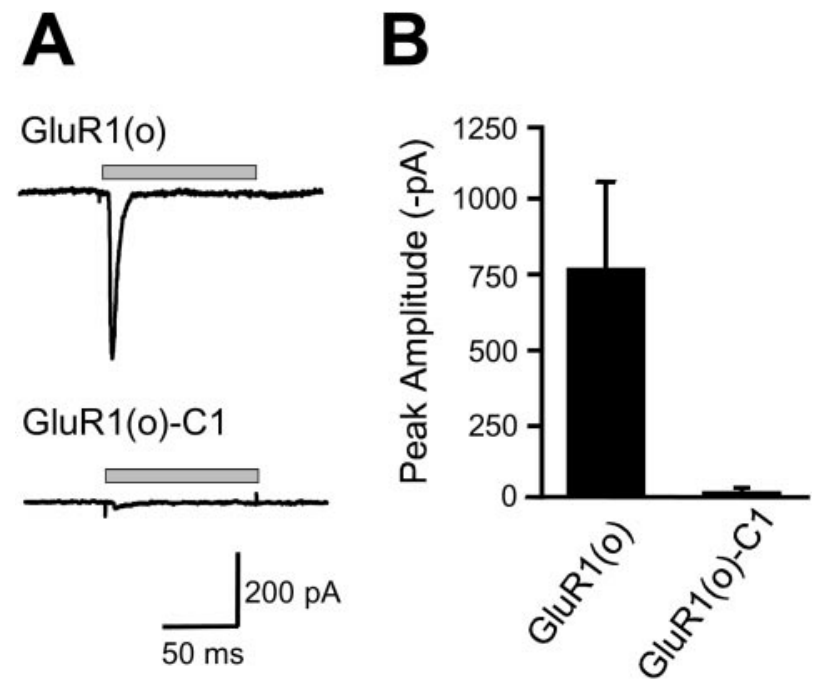

Figure 2. Introduction of the $\mathrm{C} 1$ domain into the $\mathrm{C}$ terminal of GluR1 attenuates functional expression. $A$, Currents evoked by the application of glutamate $(10 \mathrm{~mm}$ for $100 \mathrm{msec})$ were recorded from HEK293 cells expressing either wild-type homomeric GluR1 AMPA receptors [GluR1(o); top trace] or GluR1 with the NR1 C1 domain inserted within the cytoplasmic C terminus [GluR1(o)-C1; bottom trace]. Representative traces for both receptor types are shown. The gray horizontal bar indicates the time of glutamate application. Cells were voltage clamped at $-70 \mathrm{mV}$. $B$, The mean peak current amplitude was significantly larger for GluR1(o) receptors compared with GluR1(o)-C1 receptors $(767 \pm 287$ vs $17 \pm 10$ $\mathrm{pA} ; p<0.05$ in an unpaired $t$ test; $n=14$ and 10, respectively).

tion of Tac-NR1 receptors, we constructed a series of Tac-NR1a point mutants and examined their effect on ER retention. Disruption of the putative RXR ER retention/retrieval motif (KRRR892-895AAAA) released Tac-NR1a receptors from the ER in both COS7 cells (Fig. 4B, left) and hippocampal neurons (Fig. 4B, right). Quantification of surface expression using flowassisted cytometry of HEK293 cells transfected with the TacNR1a KRRR892-895AAAA mutant showed that the mutant had sixfold greater surface fluorescence than had Tac-NR1a (Fig. 4C). These results indicate that the C1 domain of NR1 contains an RXR ER retention/retrieval motif.

\section{PKC phosphorylation of NR1 releases receptors from the ER}

The C1 domain contains the major phosphorylation sites of NR1 (Tingley et al., 1993), and PKC phosphorylation within the C1 domain regulates the intracellular localization of NR1 subunits (Ehlers et al., 1995). Because these phosphorylation sites are in close proximity to the RXR ER retention motif, we hypothesized that phosphorylation might block ER retention and promote plasma membrane delivery of NMDA receptors. Surprisingly, mutations that prevent (S890A) or mimic (S890E) phosphorylation of serine 890, a known PKC phosphorylation site (Tingley et al., 1997), had no effect on surface expression of Tac-NR1a (Fig. $5 A, B)$. In addition, mutations that prevent phosphorylation of serines 896 and 897 (SS896-7AA), known PKC and PKA sites (Tingley et al., 1997), respectively, also had no effect on surface expression (Fig. 5A,B). However, Tac-NR1a receptors carrying negative-charge mutations that mimic phosphorylation at serines 896 and 897 (SS896-7EE) exhibited strong surface expression in both COS7 cells (Fig. $5 A$ ) and hippocampal neurons (Fig. $5 B$ ). Flow cytometric quantification of bound surface antibody showed 


\section{A}
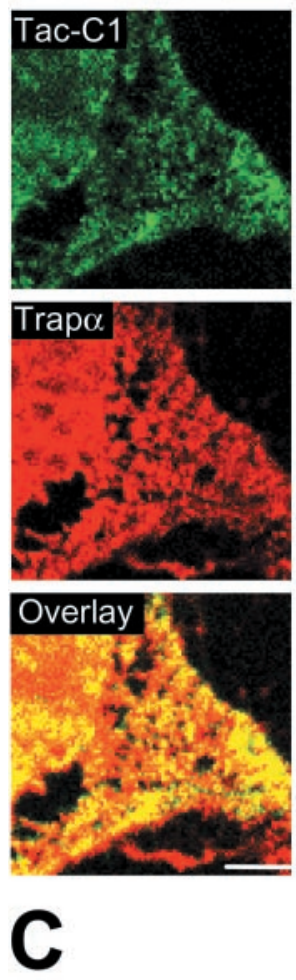

Figure 3. The $\mathrm{C} 1$ domain contains an ER retention motif. Tac-C1 and TacNR1a localize to the ER. $A, B, \mathrm{COS} 7$ cells transfected with either $\mathrm{Tac}-\mathrm{C} 1$ or Tac-NR1a were permeabilized and stained with antibodies against Tac (green) and the ER resident protein Trap $\alpha($ red $)(A)$ or with antibodies against the $\mathrm{C} 1$ domain $(r e d)$ and the ER marker $\mathrm{BiP}$ (green) (B). Image overlays showed extensive colocalization (yellow). $C$, $\mathrm{Tac}-\mathrm{C} 1$ and Tac-NR1a do not localize to Golgi compartments. Rat-1 fibroblast cells were transfected with either $\mathrm{Tac}-\mathrm{C} 1$ or Tac-NR1a and stained for Tac (red) and mannosidase II (green) to label the medial Golgi compartment. $D$, Tac-C1 and Tac-NR1a are sensitive to deglycosylation by endo $\mathrm{H}$, indicating that these receptors are retained in the ER. Tac-NR1 receptors without $\mathrm{C} 1$ are resistant to endo $\mathrm{H}$ but remain sensitive to $\mathrm{PNGase} F$, indicating that these receptors are able to leave the ER and enter the Golgi. Arrows designate mature Tac species. Arrowheads designate immature forms of Tac. Horizontal bars on the right indicate the location of the $49.5 \mathrm{kDa}$ molecular mass marker. Scale bars: $A, B, 5 \mu \mathrm{m} ; C, 10 \mu \mathrm{m}$.
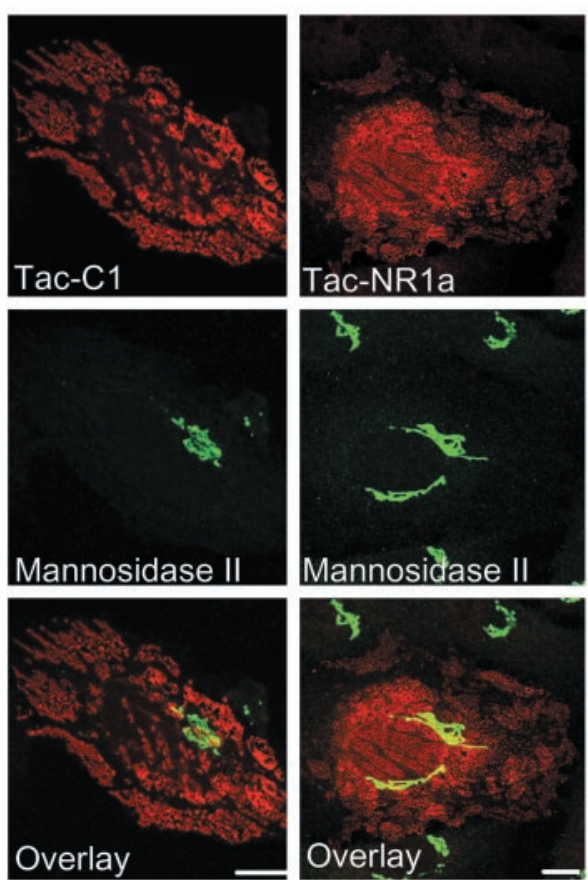
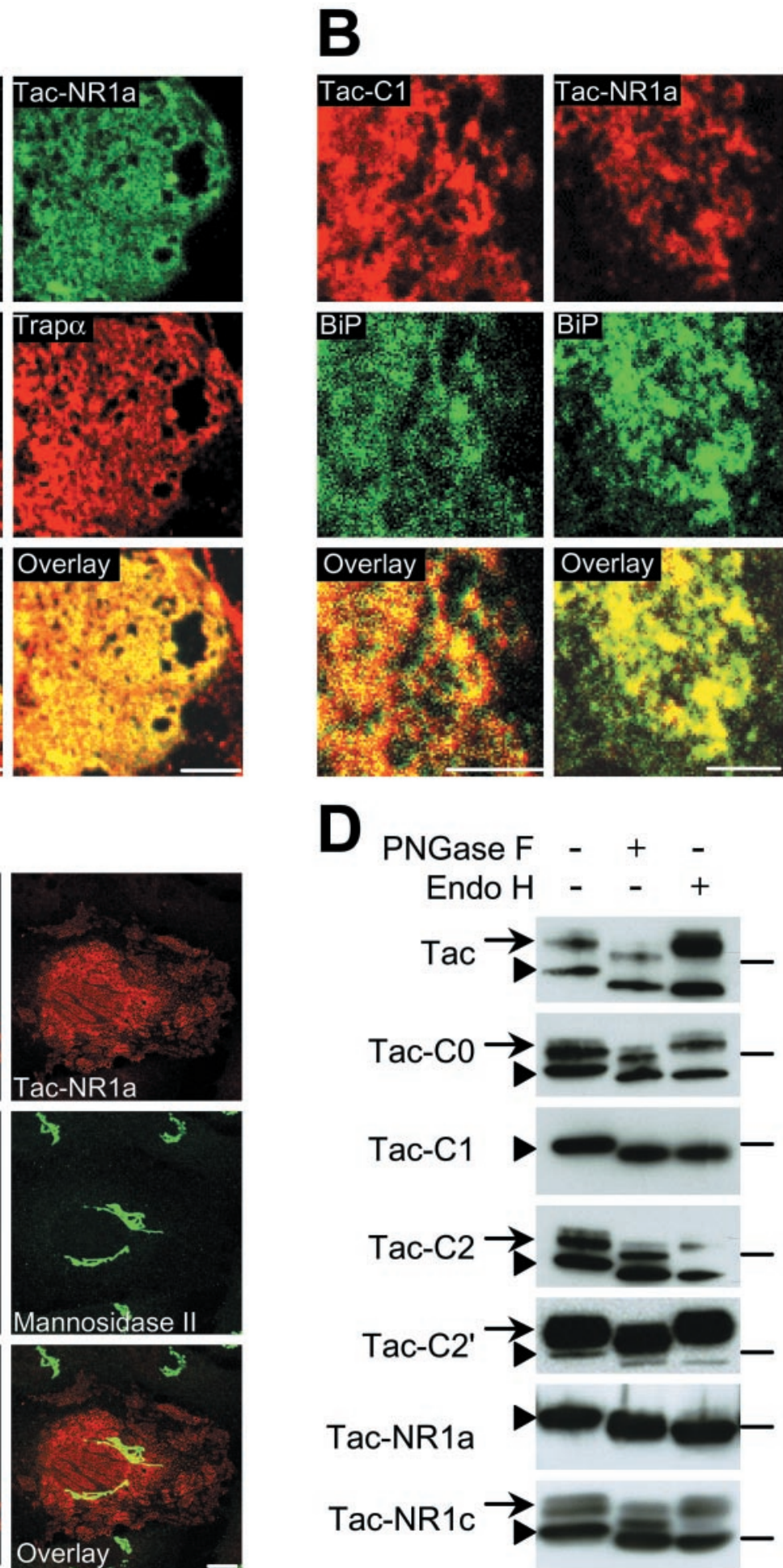

that Tac-NR1a SS896-7EE receptors were expressed at $\sim 2.5$-fold higher levels at the plasma membrane compared with the expression of Tac-NR1a (Fig. 5C), whereas none of the other phosphorylation site mutants (S890A, S890E, and SS896-7AA) showed greater surface expression than that of Tac-NR1a (Fig. 5C).

To determine whether PKC phosphorylation dynamically regulates ER retention and release of Tac-NR1 receptors, we transfected COS7 cells with either Tac-NR1a or Tac-NR1a SS8967AA and treated them with the cell-permeable PKC activator
PMA (100 nM). Activation of PKC resulted in the appearance of Tac-NR1a on the cell surface (Fig. 5D). Interestingly, very little surface expression was detected $1 \mathrm{hr}$ after incubating with PMA (data not shown). However, by 2-3 hr after a 30 min incubation with PMA, Tac-NR1a surface expression was readily detectable (Fig. 5D). This delayed appearance of Tac-NR1a is consistent with the previously reported transport kinetics of membrane proteins through the secretory pathway (Hirschberg et al., 1998). Furthermore, mutation of serines 896 and 897 to alanine com- 


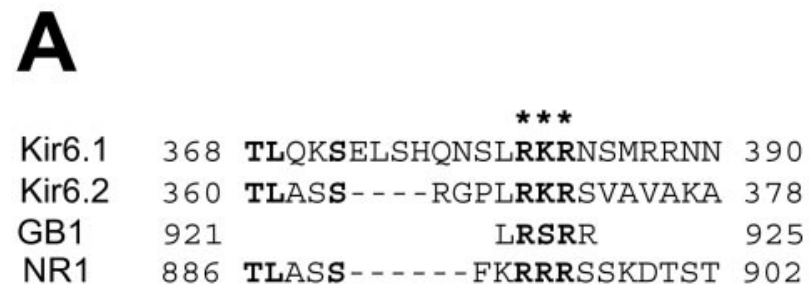

B

$\cos 7$

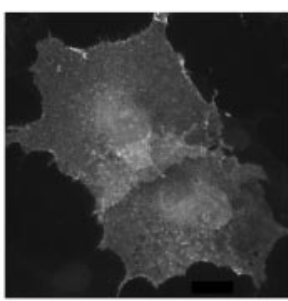

Surface

Total
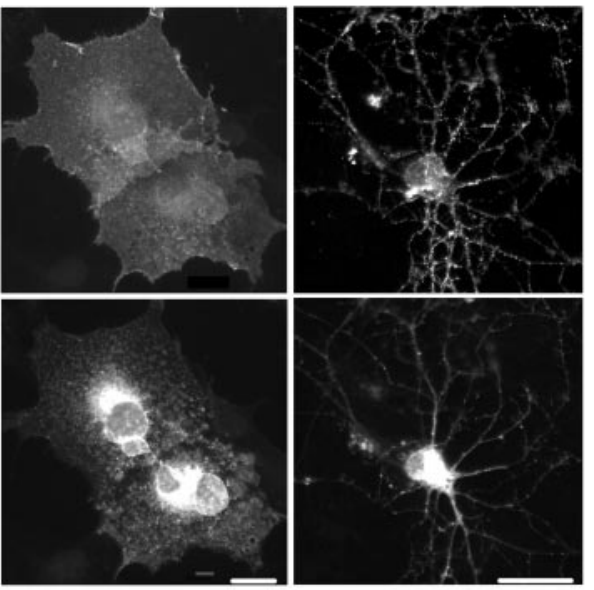

C

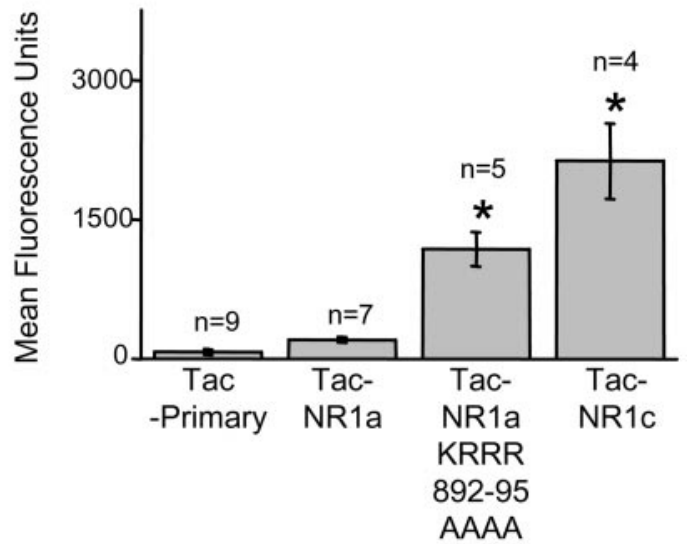

Figure 4. Identification of an RXR-type ER retention/retrieval motif in $\mathrm{NR} 1$ and key residues required for ER retention. $A$, Sequence alignment between $\mathrm{C}$-terminal domains of rat $\mathrm{K}_{\mathrm{ATP}}$ channel subunits, the rat $\mathrm{GABA}_{\mathrm{B}}$ receptor GB1 subunit, and the C1 domain of the rat NR1 subunit. The location of the RXR ER retention/retrieval motif is designated by asterisks. Note that the $\mathrm{C} 1$ domain of NR1 shares homology around this motif. $B$, Surface expression of Tac-NR1a point mutants in COS7 cells and hippocampal neurons. Tac-NR1 receptors containing mutations in the putative RXR ER retention/retrieval motif (Tac-NR1a KRRR892-895AAAA) are able to exit the ER and are expressed at the plasma membrane. $C$, Flow cytometric quantification of Tac-NR1a RXR mutant surface expression in HEK293 cells. Data represent means \pm SEM of fluorescence intensities from 4,000 to 10,000 transfected cells determined as described in Figure $1 C\left({ }^{*} p<0.05\right.$ relative to Tac minus primary antibody controls, one-way ANOVA). Scale bars, COS7, $10 \mu \mathrm{m}$; Neuron, $25 \mu \mathrm{m}$.

pletely abolished phorbol ester-induced surface expression (Fig. $5 D$, bottom panels), indicating that phosphorylation at these residues is required for PKC-mediated ER release. Quantification of these results revealed an approximately sixfold increase in the number of Tac-NR1a-expressing cells showing surface expression after PMA treatment compared with that of untreated cells (Fig. 5E). Mutation of serines 896 and 897 to alanine completely abolished this effect (Fig. 5E). Together, these findings establish a role for PKC phosphorylation of NR1 in the ER retention and plasma membrane delivery of NMDA receptors and suggest that surface levels of NMDA receptors may reflect, in part, the previous history of kinase activation at a given synapse.

\section{Suppression of RXR-mediated ER retention by an adjacent consensus PDZ-binding domain}

In addition to inserting or removing the RXR-containing $\mathrm{C} 1$ domain, alternative mRNA splicing of the NR1 C terminal domain introduces a consensus type I PDZ-binding sequence (VSTVV) (Songyang et al., 1997) adjacent to $\mathrm{C} 1$ by replacing the $\mathrm{C} 2$ domain with the $\mathrm{C} 2{ }^{\prime}$ domain (Fig. $1 A$ ). To determine the effect of the $\mathrm{C}^{2}$ ' domain on plasma membrane trafficking of NR1, we compared the surface expression of Tac-NR1a and Tac-C0$\mathrm{C} 1-\mathrm{C} 2$ ' (Tac-NR1e). Insertion of the $\mathrm{C} 2$ ' domain distal to $\mathrm{C} 1$ (Tac-NR1e) eliminated ER retention and promoted robust surface expression of Tac-NR1 in both COS7 cells (Fig. 6A) and hippocampal neurons (Fig. 6B). Tac-NR1e surface expression was approximately sevenfold greater than that of Tac-NR1a and did not differ significantly from that of Tac-NR1c or Tac-C0C2' (Tac-NR1g) (Fig. 6C). The suppression of ER retention was caused by the consensus PDZ-binding domain of $\mathrm{C}_{2}$ ', because deletion of the terminal five amino acids ( $\triangle$ VSTVV) abolished delivery of Tac-NR1e to the plasma membrane (Fig. 6A-C). Consistent with these immunocytochemical results, glycosylation state analysis revealed that Tac-NR1e was resistant to endo $\mathrm{H}$ and thus had been processed through the Golgi, whereas TacNR1e $\triangle$ VSTVV remained sensitive to endo $\mathrm{H}$ and was thus trapped in the ER (Fig. 6D). These data indicate that the alternatively spliced consensus PDZ-binding domain of $\mathrm{C}^{\prime}$ suppresses ER retention mediated by the RXR motif of $\mathrm{C} 1$ and promotes ER export and trafficking to Golgi compartments.

\section{DISCUSSION}

A variety of quality control mechanisms operate in the ER to ensure that only properly folded and assembled proteins are transported to their target organelles and compartments (Brodsky and McCracken, 1999; Ellgaard et al., 1999). ER exit serves as an important checkpoint both in coordinating the sequential assembly of multisubunit protein complexes within the ER and in defining the number of receptors expressed at the plasma membrane (Blount et al., 1990; Green and Claudio, 1993; Brodsky and McCracken, 1999; Ellgaard et al., 1999; Zerangue et al., 1999; Bichet et al., 2000; Margeta-Mitrovic et al., 2000). Here we have provided a first description of ER quality control mechanisms that regulate the plasma membrane delivery of NMDA receptors. In particular, our findings reveal the presence of an ER retention signal in the alternatively spliced $\mathrm{C}$ terminal domain of the NR1 subunit and show that release of NR1 from the ER is regulated by PKC phosphorylation and an alternatively spliced consensus PDZ-binding domain. By altering the degree or efficiency of NMDA receptor surface expression, such quality control mechanisms could modify the magnitude of NMDA receptormediated signals at the synapse, thus influencing synaptic strength, plasticity, and vulnerability to excitotoxicity.

Previous studies of ours and others have shown that the $\mathrm{C}$ 
Figure 5. PKC phosphorylation regulates ER retention of Tac-NR1a. $A$, Surface and intracellular localization of Tac-NR1a receptors mutated at phosphorylation sites in COS7 cells is shown. Mutations that block $(\mathrm{S} \rightarrow \mathrm{A})$ or mimic $(\mathrm{S} \rightarrow \mathrm{E})$ phosphorylation were introduced at serines 890,896 , and 897 . Note that unlike wildtype Tac-NR1a, Tac-NR1a receptors containing mutations that mimic phosphorylation at serines 896 and 897 (SS896-7EE) trafficked to the cell surface. $B$, Surface and intracellular localization of Tac-NR1a phosphorylation site mutants in hippocampal neurons is shown. $C$, Flow cytometric quantification of Tac-NR1a phosphorylation mutants in HEK293 cells is presented. Data represent means \pm SEM of surface fluorescence intensities from 5,000 to 10,000 transfected cells determined as described in Figure $1 C\left({ }^{*} p<0.05\right.$ compared with Tac minus primary antibody control, one-way ANOVA). $D$, Activation of PKC releases Tac-NR1a receptors from the ER. COS7 cells transfected with either Tac-NR1a or Tac-NR1a SS896-7AA were treated with $100 \mathrm{~nm}$ PMA for $30 \mathrm{~min}$ and then assayed for surface and intracellular expression 2-3 hr later. E, Quantification of PMA-induced ER release of Tac-NR1a receptors is shown. Data represent means \pm SEM of the percentage of Tac-NR1a- or Tac-NR1a SS897-7AA-transfected cells showing surface expression before or $2-3 \mathrm{hr}$ after PKC activation. PKC activation was accomplished as described in $C\left({ }^{*} p<0.05 \mathrm{com}\right.$ pared with Tac-NR1a untreated, one-way ANOVA; ${ }^{* *} p<0.05$ compared with Tac-NR1a plus PMA, one-way ANOVA). Scale bars: $A, D$, $10 \mu \mathrm{m} ; B, 25 \mu \mathrm{m}$.

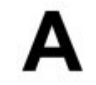

Surface

Total
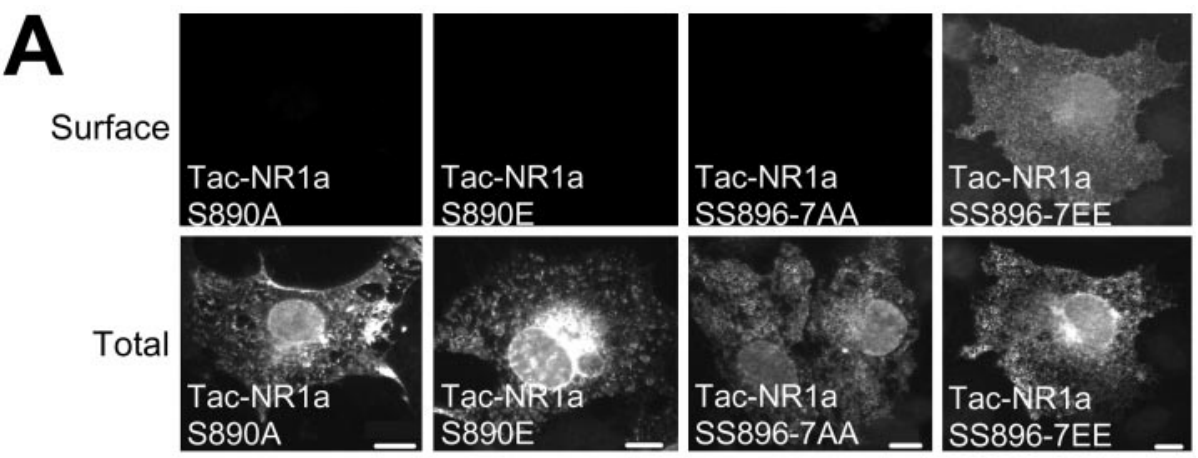

SS896-7EE
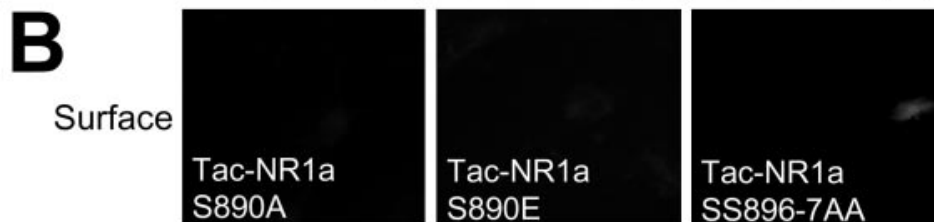

Tac-NR1a SS896-7EE

\section{Surface}
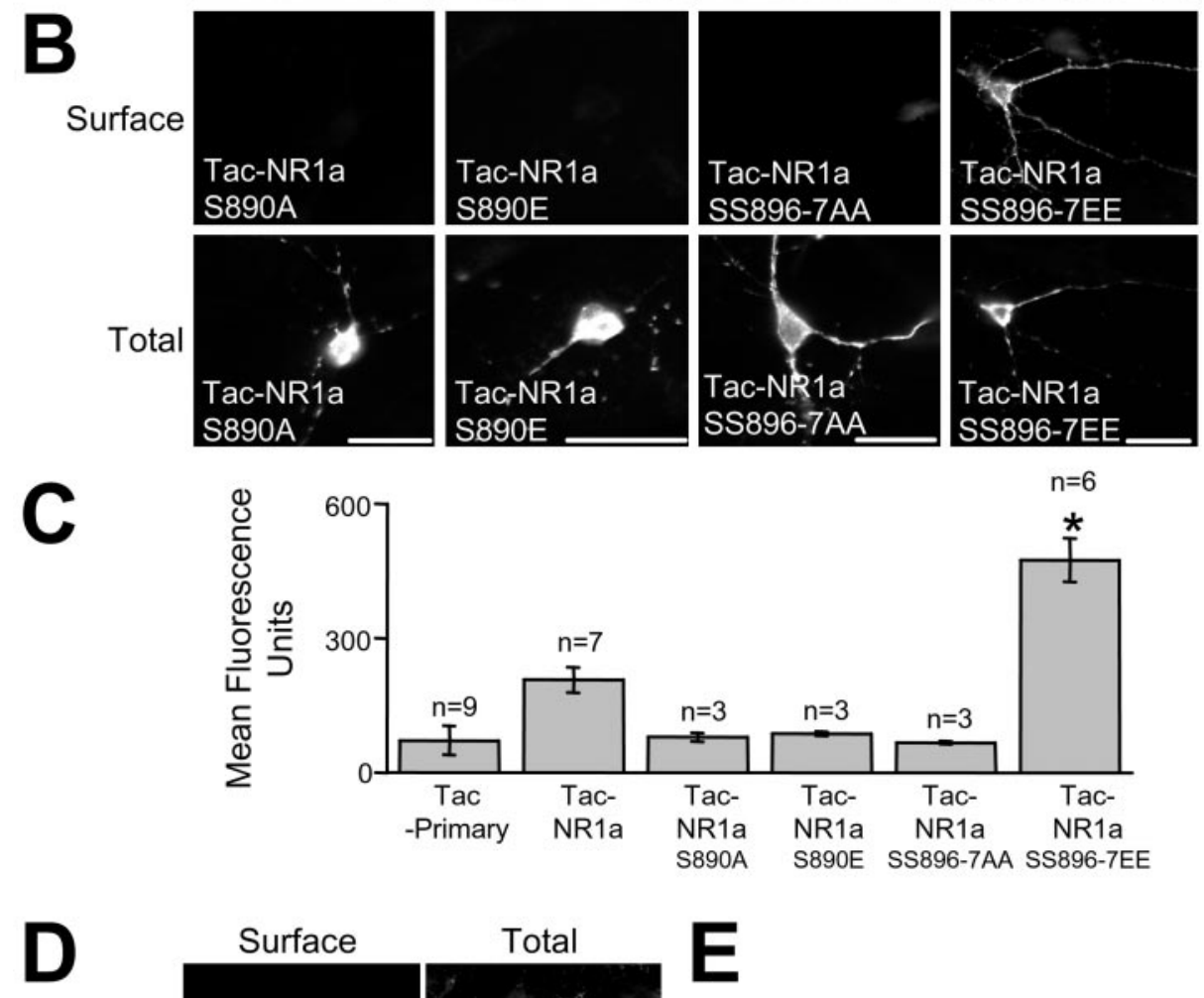

Untreated
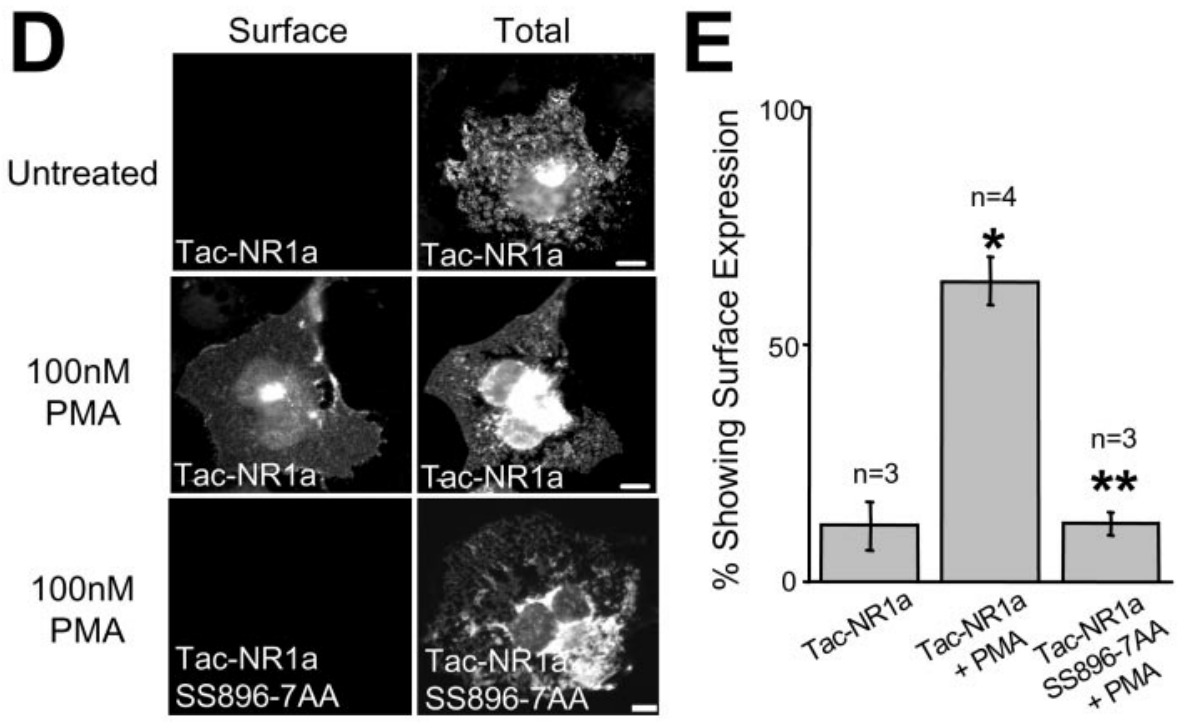

terminus of NR1 influences intracellular distribution (Ehlers et al., 1995) and surface expression (Okabe et al., 1999; Standley et al., 2000) of NR1/NR2 heteromers. To identify the relevant trafficking signals in NR1 and to minimize effects of NR2 subunits and other NR1 domains, we chose to isolate the contribu- tion of NR1 C-terminal domains using Tac-NR1 chimeras. Such an approach has been used extensively to identify signals involved in secretory and endocytic membrane trafficking (Milgram et al., 1996; Ghosh et al., 1998; Jansen et al., 1998; Tan et al., 1998; El Meskini et al., 2001). The experimental advantages of this ap- 


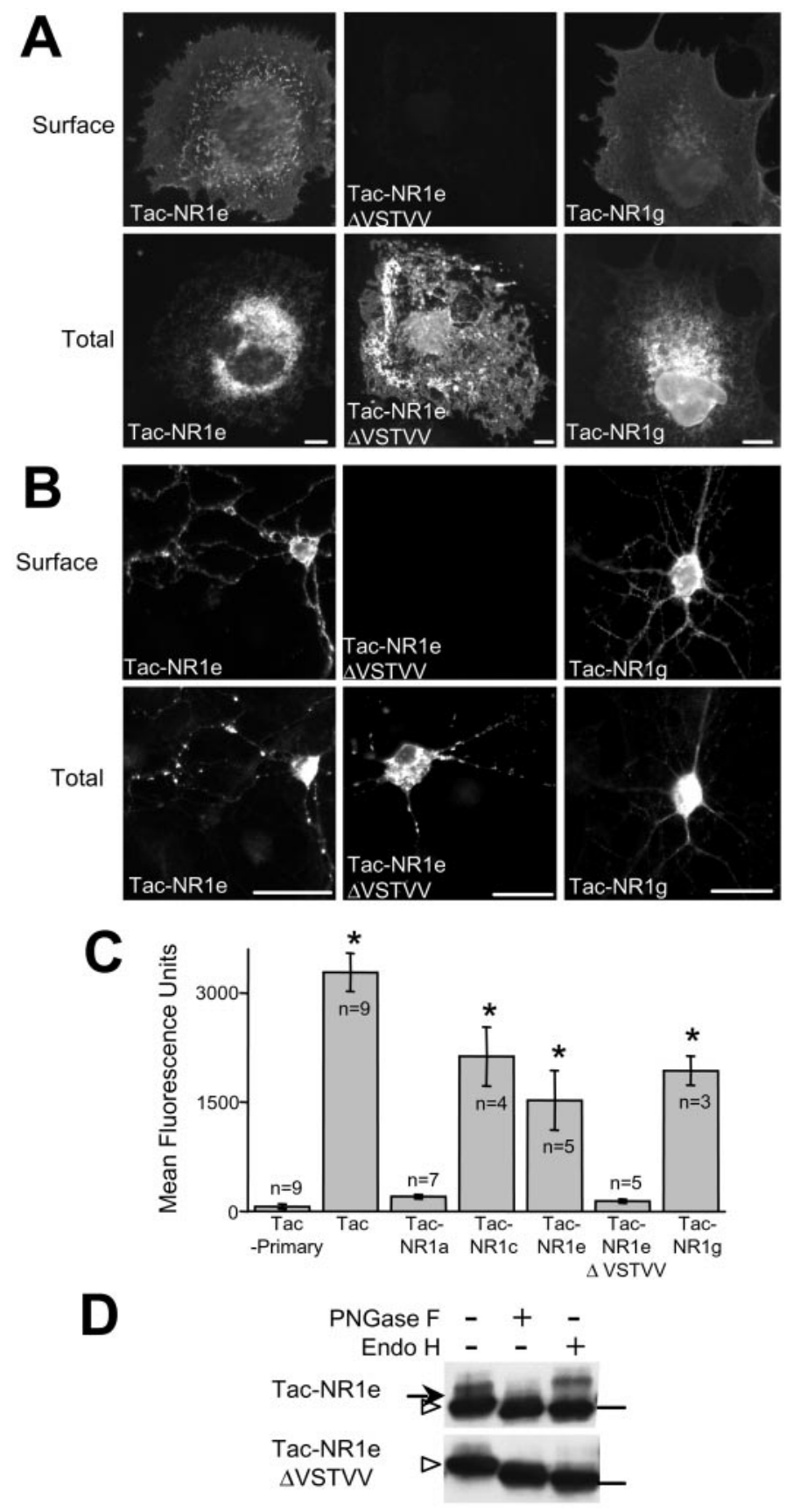

Figure 6. The PDZ-binding domain located in the C2' domain of NR1 suppresses RXR-mediated ER retention. $A$, Surface and intracellular expression of Tac-NR1 receptors in COS7 cells is shown. Receptors with the $\mathrm{C}^{\prime}$ ' domain (Tac-NR1e, Tac-NR1g) reach the plasma membrane, but deletion of the terminal PDZ-binding domain (Tac-NR1e $\Delta$ VSTVV) prevents surface expression. $B$, Surface and intracellular localization of Tac-NR1e, Tac-NR1e $\Delta$ VSTVV, and Tac-NR1g in hippocampal neurons is shown. $C$, Quantification of Tac-NR1 chimeras in HEK293 cells is presented. The fluorescence intensity of 5,00010,000 transfected cells was determined as described in Figure $1 C$ $\left({ }^{*} p<0.05\right.$ compared with Tac minus primary antibody control, oneway ANOVA). $D$, Tac-NR1e $\triangle$ VSTVV is sensitive to deglycosylation by endo $\mathrm{H}$, indicating that it is retained in the ER. Tac-NR1e is resistant to endo $\mathrm{H}$ but remains sensitive to PNGase F, indicating that it is able to leave the ER and enter the Golgi. Arrows designate mature forms of Tac. Arrowheads designate immature Tac proteins. Horizontal bars on the right indicate the location of the $49.5 \mathrm{kDa}$ molecular mass marker. Scale bars: $A, 10 \mu \mathrm{m} ; B, 25 \mu \mathrm{m}$. proach include the well characterized nature of the Tac protein and its trafficking, the existence of highly specific extracellular epitope antibodies, and the monomeric nature of the Tac chimeras. Moreover, by isolating specific domains of NR1 via Tac fusions, we were able to identify RXR trafficking signals that might normally be masked during subunit assembly (Zerangue et al., 1999).

\section{The RXR motif: a growing family of ER retention/retrieval signals}

Recent work on $\mathrm{K}_{\mathrm{ATP}}$ potassium channels and $\mathrm{GABA}_{\mathrm{B}}$ receptors has revealed a novel class of RXR ER retention/retrieval motifs (Zerangue et al., 1999; Margeta-Mitrovic et al., 2000). These cytoplasmic RXR motifs differ from the classic KKXX cytoplasmic ER retention motifs in that location of the RXR is not limited to the most C-terminal domain of the molecule (Teasdale and Jackson, 1996; Zerangue et al., 1999; MargetaMitrovic et al., 2000). Here we report the identification of a similar RXR motif in an intracellular domain of NR1. This motif, also recently reported by Wenthold and colleagues (Standley et al., 2000), extends the reported RXR family to include ligand-gated ion channels, as well as potassium channels, ATP-binding cassette proteins, and G-protein-coupled receptors (Zerangue et al., 1999; Bichet et al., 2000; MargetaMitrovic et al., 2000), and suggests that the RXR ER retention/retrieval motif is a general quality control mechanism governing the ER exit of multisubunit membrane proteins.

In other RXR-containing proteins, RXR motifs are masked by assembly with additional subunits and thus coordinate the assembly and stoichiometry of mature receptor complexes (Zerangue et al., 1999; Margeta-Mitrovic et al., 2000). As with $\mathrm{K}_{\mathrm{ATP}}$ channels and $\mathrm{GABA}_{\mathrm{B}}$ receptors, NMDA receptors are heteromeric protein complexes comprised of multiple polypeptide subunits (NR1 and NR2) that must coassemble to form a functional receptor channel. Although this study has focused on the NR subunit, it is likely that efficient assembly and trafficking of NMDA receptors through the secretory pathway will depend on additional as yet unidentified domains in both NR1 and NR2. Indeed, C-terminal domains of NR2 are required for efficient synaptic targeting of NMDA receptors (Mori et al., 1998; Sprengel et al., 1998; Steigerwald et al., 2000), and N-terminal extracellular regions are required for efficient assembly and ER exit of AMPA receptor subunits (Leuschner and Hoch, 1999).

It is tempting to speculate that the obligate heteromeric nature of NMDA receptors arises, in part, because of NR2-dependent masking of NR1 ER retention domains. Alternatively, NR2 subunits may facilitate surface expression by providing an ER export signal (Ma et al., 2001) that competes with RXR-mediated ER retention. The recently appreciated complexity of ER retention and ER export signals present in $\mathrm{K}^{+}$channels (Zerangue et al., 1999; Schwappach et al., 2000; Ma et al., 2001) raises the possibility that multiple mechanisms and signals regulate NMDA receptor trafficking through the ER and Golgi. In particular, NR2 forward-trafficking signals, NR2-dependent masking of ER retention motifs, and phosphorylation-dependent masking of ER retention motifs could each contribute at different stages in the secretory pathway.

It will be important for future studies to determine how ER retention motifs in NR1 interact with NR2 to orchestrate NMDA receptor assembly, as well as identify the relationship between NR1 RXR domains and other trafficking signals within mature NMDA receptor complexes. Furthermore, additional intracellu- 
lar signaling mechanisms may control the plasma membrane expression of RXR-containing protein complexes independent of multisubunit assembly. For example, our work demonstrates that protein phosphorylation and the introduction of a consensus PDZ-binding domain near the RXR motif can block RXRmediated ER retention/retrieval.

\section{PDZ interactions and intracellular trafficking of NMDA receptors}

PDZ proteins play a prominent role in efficiently trafficking, localizing, and/or anchoring membrane proteins and signaling molecules to discrete cellular subdomains (Fanning and Anderson, 1999; Garner et al., 2000). In the case of NMDA receptors, NR2 C-terminal domains interact with PDZ domains of the synaptic scaffolding protein postsynaptic density-95 and related family members to target and anchor NMDA receptor complexes at synapses (Garner et al., 2000; Sheng and Lee, 2000). Unlike the PDZ-binding motifs of NR2 subunits (IESDV), the binding partners and cellular function of the consensus C2' PDZ-binding motif (VSTVV) of NR1 remain unknown [Bassand et al. (1999), but see Kornau et al. (1995)].

Our work demonstrates that the consensus C2' PDZ-binding motif of NR1 antagonizes the RXR ER retention/retrieval motif found in $\mathrm{C} 1$. These results are in agreement with a recent study identifying suppression of NR1 ER retention via the C2' consensus PDZ-binding domain (Standley et al., 2000). This ERreleasing activity is the first ascribed function for this potential PDZ-binding domain and raises the possibility that PDZmediated interactions play a more "active" role in the early events of NMDA receptor trafficking. Indeed, efficient anterograde trafficking and plasma membrane delivery of pro-TGF- $\alpha$ is dependent on the PDZ-mediated interaction between a very similar C-terminal TVV sequence in pro-TGF- $\alpha$ and syntenin/TACIP18 (Fernandez-Larrea et al., 1999). In addition, PDZ domainmediated active transport has been implicated recently in the trafficking of NMDA receptor-containing vesicles along microtubules in neuronal dendrites by linking NR2 subunits to the motor protein KIF17 via a Lin7/Lin2/Lin10 PDZ protein complex (Setou et al., 2000). Importantly, because C2' domain-binding partners are currently unknown, we cannot exclude the possibility that the VSTVV motif mediates forward trafficking of NMDA receptors via non-PDZ interactions. It will be important for future studies to identify $\mathrm{C}^{\prime}$ ' domain-binding partners and determine their functional role in ER-Golgi transport of NMDA receptors.

\section{PKC phosphorylation and plasma membrane insertion of NMDA receptors}

Accumulation of glutamate receptors in the postsynaptic membrane is regulated by synaptic activity and is a critical feature of synapse formation (Luscher et al., 2000; Malinow et al., 2000). The plasma membrane insertion of new NMDA receptors occurs within 1-2 hr of initial contact by an active presynaptic terminal (Friedman et al., 2000), and at more mature synapses, synaptic insertion is proposed to occur within hours of experiencedependent activation (Quinlan et al., 1999). In addition, chronic increases or decreases in the level of synaptic activity cause reciprocal changes in the synaptic accumulation of NMDA receptors (Rao and Craig, 1997; Liao et al., 1999; Watt et al., 2000). Such dynamic control of NMDA receptor membrane insertion may occur by regulated release of NMDA channels from the ER.

Our results indicate that potential PDZ interactions and phos- phorylation dynamically regulate NMDA receptor ER retention. Interestingly, previous studies have shown that PKC activation potentiates NMDA receptor activity in neurons (Chen and Huang, 1992; MacDonald et al., 1998), perhaps by promoting the surface delivery of receptors. However, PKC potentiation of NMDA receptor activity is not dependent on phosphorylation of the C1 domain (Sigel et al., 1994; Zheng et al., 1999) and occurs within minutes of phorbol ester treatment (Chen and Huang, 1992; Sigel et al., 1994). In contrast, we find that PKC phosphorylation relieves NMDA receptor ER retention, leading to robust surface expression of receptors after 2-3 hr. This latency in surface expression suggests that the number of NMDA receptors at the plasma membrane may reflect kinase signaling events that occurred hours earlier. In addition, the delay we observe in the insertion of NMDA receptors at the plasma membrane is consistent with the time course of synaptogenesis- and experiencedependent insertion of NMDA receptors (Quinlan et al., 1999; Friedman et al., 2000). Although the initial appearance of NMDA receptors at the plasma membrane after PKC activation may occur earlier than the peak surface expression at 2-3 hr, these findings suggest that phorbol ester potentiation of NMDA receptor activity and PKC-mediated suppression of NMDA receptor ER retention are mechanistically distinct processes.

Note added in proof. After submission of this manuscript, two additional studies have reported ER retention/retrieval motifs in $\mathrm{GABA}_{\mathrm{B}}$ receptors (Calver et al., 2001; Pagano et al., 2001).

\section{REFERENCES}

Bassand P, Bernard A, Rafiki A, Gayet D, Khrestchatisky M (1999) Differential interaction of the tSXV motifs of the NR1 and NR2A NMDA receptor subunits with PSD-95 and SAP97. Eur J Neurosci 11:2031-2043.

Bichet D, Cornet V, Geib S, Carlier E, Volsen S, Hoshi T, Mori Y, De Waard M (2000) The I-II loop of the $\mathrm{Ca}^{2+}$ channel alpha1 subunit contains an endoplasmic reticulum retention signal antagonized by the beta subunit. Neuron 25:177-190.

Blount P, Smith MM, Merlie JP (1990) Assembly intermediates of the mouse muscle nicotinic acetylcholine receptor in stably transfected fibroblasts. J Cell Biol 111:2601-2611.

Brodsky JL, McCracken AA (1999) ER protein quality control and proteasome-mediated protein degradation. Semin Cell Dev Biol 10:507-513.

Burke B, Griffiths G, Reggio H, Louvard D, Warren G (1982) A monoclonal antibody against a $135-\mathrm{K}$ Golgi membrane protein. EMBO J $1: 1621-1628$.

Calver AR, Robbins MJ, Cosio C, Rice SQ, Babbs AJ, Hirst WD, Bayfield I, Wood MD, Russell RB, Price GW, Couve A, Moss SJ, Pangalos MN (2001) The C-terminal domains of the $\mathrm{GABA}_{\mathrm{B}}$ receptor subunits mediate intracellular trafficking but are not required for receptor signaling. J Neurosci 21:1203-1210.

Chen L, Huang LY (1992) Protein kinase C reduces $\mathrm{Mg}^{2+}$ block of NMDA-receptor channels as a mechanism of modulation. Nature 356:521-523.

Craven SE, Bredt DS (2000) Synaptic targeting of the postsynaptic density protein PSD-95 mediated by a tyrosine-based trafficking signal. J Biol Chem 275:20045-20051.

Ehlers MD, Tingley WG, Huganir RL (1995) Regulated subcellular distribution of the NR1 subunit of the NMDA receptor. Science 269:1734-1737.

Ellgaard L, Molinari M, Helenius A (1999) Setting the standards: quality control in the secretory pathway. Science 286:1882-1888.

El Meskini R, Galano GJ, Marx R, Mains RE, Eipper BA (2001) Targeting of membrane proteins to the regulated secretory pathway in anterior pituitary endocrine cells. J Biol Chem 276:3384-3393.

Fanning AS, Anderson JM (1999) PDZ domains: fundamental building blocks in the organization of protein complexes at the plasma membrane. J Clin Invest 103:767-772.

Fernandez-Larrea J, Merlos-Suarez A, Urena JM, Baselga J, Arribas J (1999) A role for a PDZ protein in the early secretory pathway for the targeting of proTGF-alpha to the cell surface. Mol Cell 3:423-433.

Friedman HV, Bresler T, Garner CC, Ziv NE (2000) Assembly of new individual excitatory synapses: time course and temporal order of synaptic molecule recruitment. Neuron 27:57-69.

Garner CC, Nash J, Huganir RL (2000) PDZ domains in synapse assembly and signalling. Trends Cell Biol 10:274-280. 
Ghosh RN, Mallet WG, Soe TT, McGraw TE, Maxfield FR (1998) An endocytosed TGN38 chimeric protein is delivered to the TGN after trafficking through the endocytic recycling compartment in $\mathrm{CHO}$ cells. J Cell Biol 142:923-936.

Green WN, Claudio T (1993) Acetylcholine receptor assembly: subunit folding and oligomerization occur sequentially. Cell 74:57-69.

Hall RA, Soderling TR (1997) Differential surface expression and phosphorylation of the $N$-methyl-D-aspartate receptor subunits NR1 and NR2 in cultured hippocampal neurons. J Biol Chem 272:4135-4140.

Hartmann E, Prehn S (1994) The N-terminal region of the alpha-subunit of the TRAP complex has a conserved cluster of negative charges. FEBS Lett 349:324-326.

Hirschberg K, Miller CM, Ellenberg J, Presley JF, Siggia ED, Phair RD, Lippincott-Schwartz J (1998) Kinetic analysis of secretory protein traffic and characterization of Golgi to plasma membrane transport intermediates in living cells. J Cell Biol 143:1485-1503.

Huh KH, Wenthold RJ (1999) Turnover analysis of glutamate receptors identifies a rapidly degraded pool of the $N$-methyl-D-aspartate receptor subunit, NR1, in cultured cerebellar granule cells. J Biol Chem 274:151-157.

Jansen EJ, Holthuis JC, McGrouther C, Burbach JP, Martens GJ (1998) Intracellular trafficking of the vacuolar $\mathrm{H}+$-ATPase accessory subunit Ac45. J Cell Sci 111:2999-3006.

Kornau HC, Schenker LT, Kennedy MB, Seeburg PH (1995) Domain interaction between NMDA receptor subunits and the postsynaptic density protein PSD-95. Science 269:1737-1740.

Leonard WJ, Depper JM, Robb RJ, Waldmann TA, Greene WC (1983) Characterization of the human receptor for T-cell growth factor. Proc Natl Acad Sci USA 80:6957-6961.

Leuschner WD, Hoch W (1999) Subtype-specific assembly of alphaamino-3-hydroxy-5-methyl-4-isoxazole propionic acid receptor subunits is mediated by their N-terminal domains. J Biol Chem 274:16907-16916.

Liao D, Zhang X, O’Brien R, Ehlers MD, Huganir RL (1999) Regulation of morphological postsynaptic silent synapses in developing hippocampal neurons. Nat Neurosci 2:37-43.

Luscher C, Nicoll RA, Malenka RC, Muller D (2000) Synaptic plasticity and dynamic modulation of the postsynaptic membrane. Nat Neurosci 3:545-550.

Ma D, Zerangue N, Lin Y, Collins A, Yu M, Jan Y, Jan L (2001) Role of ER export signals in controlling surface potassium channel numbers. Science 291:316-319.

MacDonald JF, Xiong XG, Lu WY, Raouf R, Orser BA (1998) Modulation of NMDA receptors. Prog Brain Res 116:191-208.

Malenka RC, Nicoll RA (1999) Long-term potentiation-a decade of progress? Science 285:1870-1874.

Malinow R, Mainen ZF, Hayashi Y (2000) LTP mechanisms: from silence to four-lane traffic. Curr Opin Neurobiol 10:352-357.

Margeta-Mitrovic M, Jan YN, Jan LY (2000) A trafficking checkpoint controls GABA(B) receptor heterodimerization. Neuron 27:97-106.

McIlhinney RA, Molnar E, Atack JR, Whiting PJ (1996) Cell surface expression of the human $N$-methyl-D-aspartate receptor subunit 1 a requires the co-expression of the $\mathrm{NR} 2 \mathrm{~A}$ subunit in transfected cells. Neuroscience 70:989-997.

McIlhinney RA, Le Bourdelles B, Molnar E, Tricaud N, Streit P, Whiting PJ (1998) Assembly intracellular targeting and cell surface expression of the human $N$-methyl-D-aspartate receptor subunits NR1a and NR2A in transfected cells. Neuropharmacology 37:1355-1367.

Milgram SL, Mains RE, Eipper BA (1996) Identification of routing determinants in the cytosolic domain of a secretory granule-associated integral membrane protein. J Biol Chem 271:17526-17535.

Monyer H, Sprengel R, Schoepfer R, Herb A, Higuchi M, Lomeli H, Burnashev N, Sakmann B, Seeburg PH (1992) Heteromeric NMDA receptors: molecular and functional distinction of subtypes. Science 256:1217-1221.

Mori H, Mishina M (1995) Structure and function of the NMDA receptor channel. Neuropharmacology 34:1219-1237.

Mori H, Manabe T, Watanabe M, Satoh Y, Suzuki N, Toki S, Nakamura K, Yagi T, Kushiya E, Takahashi T, Inoue Y, Sakimura K, Mishina M (1998) Role of the carboxy-terminal region of the GluR epsilon2 subunit in synaptic localization of the NMDA receptor channel. Neuron 21:571-580.

O’Brien RJ, Lau LF, Huganir RL (1998) Molecular mechanisms of glutamate receptor clustering at excitatory synapses. Curr Opin Neurobiol 8:364-369.
Okabe S, Miwa A, Okado H (1999) Alternative splicing of the $\mathrm{C}$-terminal domain regulates cell surface expression of the NMDA receptor NR1 subunit. J Neurosci 19:7781-7792.

Ozawa S, Kamiya H, Tsuzuki K (1998) Glutamate receptors in the mammalian central nervous system. Prog Neurobiol 54:581-618.

Pagano A, Rovelli G, Mosbacher J, Lohmann T, Duthey B, Stauffer D, Ristig D, Schuler V, Meigel I, Lampert C, Stein T, Prezeau L, Blahos J, Pin JP, Froestl W, Kuhn R, Heid J, Kaupmann K, Behler B (2001) $\mathrm{C}$-terminal interaction is essential for surface trafficking but not for

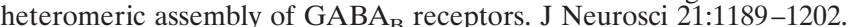

Quinlan EM, Philpot BD, Huganir RL, Bear MF (1999) Rapid, experience-dependent expression of synaptic NMDA receptors in visual cortex in vivo. Nat Neurosci 2:352-357.

Rao A, Craig AM (1997) Activity regulates the synaptic localization of the NMDA receptor in hippocampal neurons. Neuron 19:801-812.

Sanders SL, Schekman R (1992) Polypeptide translocation across the endoplasmic reticulum membrane. J Biol Chem 267:13791-13794.

Schwappach B, Zerangue N, Jan YN, Jan LY (2000) Molecular basis for $\mathrm{K}(\mathrm{ATP})$ assembly: transmembrane interactions mediate association of a $\mathrm{K}+$ channel with an ABC transporter. Neuron 26:155-167.

Setou M, Nakagawa T, Seog DH, Hirokawa N (2000) Kinesin superfamily motor protein KIF17 and mLin-10 in NMDA receptor-containing vesicle transport. Science 288:1796-1802.

Sheng M, Lee SH (2000) Growth of the NMDA receptor industrial complex. Nat Neurosci 3:633-635.

Sigel E, Baur R, Malherbe P (1994) Protein kinase C transiently activated heteromeric $N$-methyl-D-aspartate receptor channels independent of the phosphorylatable C-terminal splice domain and of consensus phosphorylation sites. J Biol Chem 269:8204-8208.

Songyang Z, Fanning AS, Fu C, Xu J, Marfatia SM, Chishti AH, Crompton A, Chan AC, Anderson JM, Cantley LC (1997) Recognition of unique carboxyl-terminal motifs by distinct PDZ domains. Science 275:73-77.

Sprengel R, Suchanek B, Amico C, Brusa R, Burnashev N, Rozov A, Hvalby O, Jensen V, Paulsen O, Andersen P, Kim JJ, Thompson RF, Sun W, Webster LC, Grant SG, Eilers J, Konnerth A, Li J, McNamara JO, Seeburg PH (1998) Importance of the intracellular domain of NR2 subunits for NMDA receptor function in vivo. Cell 92:279-289.

Standley S, Roche KW, McCallum J, Sans N, Wenthold RJ (2000) PDZ domain suppression of an ER retention signal in NMDA receptor NR1 splice variants. Neuron 28:887-898.

Steigerwald F, Schulz TW, Schenker LT, Kennedy MB, Seeburg PH, Kohr G (2000) C-terminal truncation of NR2A subunits impairs synaptic but not extrasynaptic localization of NMDA receptors. J Neurosci 20:4573-4581.

Tan PK, Waites C, Liu Y, Krantz DE, Edwards RH (1998) A leucinebased motif mediates the endocytosis of vesicular monoamine and acetylcholine transporters. J Biol Chem 273:17351-17360.

Tarentino AL, Gomez CM, Plummer Jr TH (1985) Deglycosylation of asparagine-linked glycans by peptide: $N$-glycosidase F. Biochemistry 24:4665-4671.

Teasdale RD, Jackson MR (1996) Signal-mediated sorting of membrane proteins between the endoplasmic reticulum and the Golgi apparatus. Annu Rev Cell Dev Biol 12:27-54.

Tingley WG, Roche KW, Thompson AK, Huganir RL (1993) Regulation of NMDA receptor phosphorylation by alternative splicing of the C-terminal domain. Nature 364:70-73.

Tingley WG, Ehlers MD, Kameyama K, Doherty C, Ptak JB, Riley CT, Huganir RL (1997) Characterization of protein kinase A and protein kinase $\mathrm{C}$ phosphorylation of the $N$-methyl-D-aspartate receptor NR1 subunit using phosphorylation site-specific antibodies. J Biol Chem 272:5157-5166.

Trimble RB, Maley F (1984) Optimizing hydrolysis of N-linked highmannose oligosaccharides by endo-beta- $N$-acetylglucosaminidase $\mathrm{H}$. Anal Biochem 141:515-522.

Watt AJ, van Rossum MC, MacLeod KM, Nelson SB, Turrigiano GG (2000) Activity coregulates quantal AMPA and NMDA currents at neocortical synapses. Neuron 26:659-670.

Zerangue N, Schwappach B, Jan YN, Jan LY (1999) A new ER trafficking signal regulates the subunit stoichiometry of plasma membrane K(ATP) channels. Neuron 22:537-548.

Zheng X, Zhang L, Wang AP, Bennett MV, Zukin RS (1999) Protein kinase $\mathrm{C}$ potentiation of $N$-methyl-D-aspartate receptor activity is not mediated by phosphorylation of $N$-methyl-D-aspartate receptor subunits. Proc Natl Acad Sci USA 96:15262-15267. 